\title{
Optimizing the technique of laparoscopic splenectomy in children
}

\author{
Józef Dzielicki, Andrzej Grabowski, Wojciech Korlacki \\ Department of Pediatric Surgery, Silesian Medical University, Zabrze, Poland
}

Videosurgery and other miniinvasive techniques 2010; 5 (1): 19-26 DOI: 10.5114/wiitm.2010.13602

\begin{abstract}
Introduction: The first laparoscopic splenectomy in children was managed in 1993 by Tulman. During the past 15 years, laparoscopic splenectomy has become a gold standard in many centres.

Aim: To establish an optimal surgical technique of laparoscopic splenectomy according to our own experience and concerning clinical and economic aspects.

Material and methods: In 1996-2007, 77 laparoscopic splenectomies were carried out in our department. Most of the indications were haematological diseases. Three groups were created from the study population according to the instruments used for preparation and closure of the vessels. Attention was paid to duration of the procedure, complications, conversions, volume of postoperative blood loss, time of analgesic therapy and length of hospital stay.

Results: Mean duration of the procedure was $112 \pm 53.11 \mathrm{~min}$. Complication rate was $12.98 \%$. There were no statistically significant differences among the three studied groups concerning the number and character of complications. Costs were significantly different in all three groups.

Conclusions:

1. There are no statistically significant differences in the clinical aspects of perioperative course among the three studied groups.

2. The use of disposable instruments and especially LigaSure high energy coagulation essentially lowers overall costs of the procedure.
\end{abstract}

Key words: laparoscopy, splenectomy, operational technique, children.

\section{Introduction}

The first laparoscopic splenectomy in a child was performed by Tulman in 1993 [1]. During the following years laparoscopic splenectomy became a gold standard in many centres [2, 3].

In our department laparoscopic splenectomy was performed for the first time on 27 March 1996. Since then, all splenectomies were performed laparoscopically with minor modifications of the technique, resulting from growing experience and improvements in the laparoscopic armamentarium.
Aim

The aim of the study was to assess techniques of laparoscopic splenectomy based on our own material and to find an optimal modification, considering both clinical and economic issues.

\section{Material and methods}

During 1996-2006 laparoscopic splenectomy was performed in 77 children. Their demographic data are shown in Table I. Patients with haematological disor- 
Table I. General data of patients

\begin{tabular}{|c|c|c|}
\hline & Data & Number \\
\hline \multirow[t]{2}{*}{ Sex } & Girls & 38 \\
\hline & Boys & 39 \\
\hline Age & 2-12 years & $\begin{array}{c}\text { mean } 12 \pm 4.12 \\
\text { years }\end{array}$ \\
\hline Body weight & $13-87 \mathrm{~kg}$ & $\begin{array}{l}\text { Mean } 46.6 \\
\pm 16.26 \mathrm{~kg}\end{array}$ \\
\hline \multirow[t]{7}{*}{ Indications } & Spherocytosis for surgery & 40 \\
\hline & Thrombocytopenia & 23 \\
\hline & $\begin{array}{l}\text { Non-spherocytic } \\
\text { haemolytic anaemia }\end{array}$ & 3 \\
\hline & Hodgkin lymphoma & 1 \\
\hline & Portal hypertension & 6 \\
\hline & Cyst of the spleen & 3 \\
\hline & Tumour of the pancreas & 1 \\
\hline
\end{tabular}

ders were referred for surgery by their haematologists. Failure of steroid therapy was an indication in chronic idiopathic thrombocytopenia [4]. In spherocytosis and non-spherocytosis anaemia indications for surgery were frequent haemolytic crises, splenomegaly with risk of capsule rupture, coexistent cholecystolithiasis or aplastic crisis [5]. In splenic cysts and portal hypertension the surgeon made the decision himself [6]. Splenectomy in portal hypertension was one of the elements of devascularization of the oesophagus.

Prior to surgery, all patients received prophylaxis against Streptococcus pneumoniae and Neisseria meningitidis infection, and children younger than 5 years additionally received vaccination against type B Haemophilus influenzae [7]. Peri- and postoperative antibiotic prophylaxis was also applied.

\section{Surgical method}

All procedures were performed by two surgeons experienced in laparoscopy assisted by a specialist surgeon or resident and nurses experienced in laparoscopic surgery instrumentation.

The procedure was performed in general anesthesia, with endotracheal intubation and patient positioning $30-45^{\circ}$ on the right side, supported from the back side. When accessory procedures were done (cholecystectomy, cholecystotomy, devascularization and fundoplication) after removal of the spleen, the position was changed to supine. Trocars were placed in two different configurations, according to the age (height) of a patient. In adolescents trocars were placed along the left costal arch. In younger children due to small space of the abdominal cavity trocars were placed more distant to the ribs (Figure 1).
A

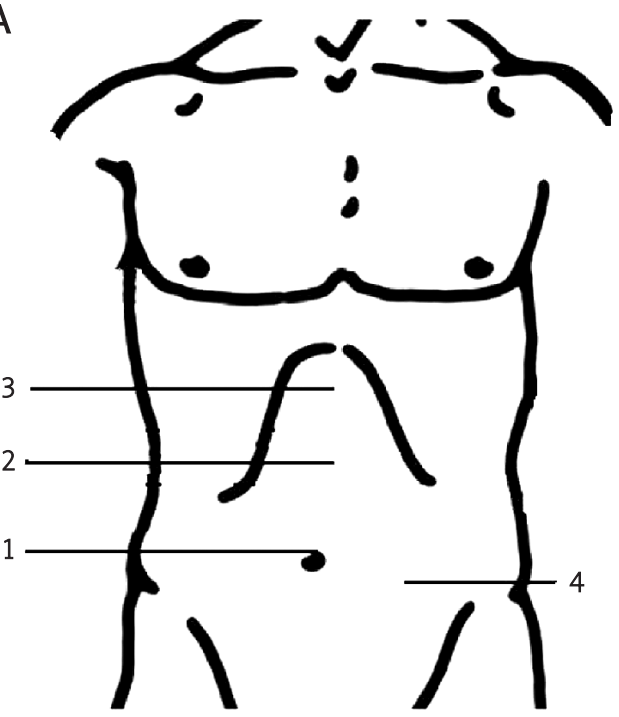

B

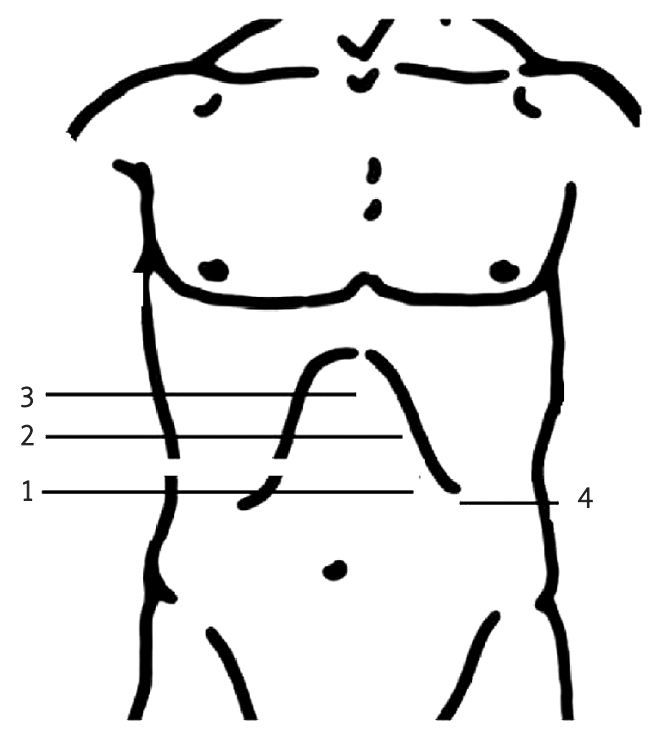

Figure 1. Trocars positioning

A - younger children, B - older children, 1 - trocar with laparoscopic optics, 2, 3-trocars for 5-mm preparation tools, 4-10 mm trocar for vessel-closing device 
The procedure was started by mobilizing the lower pole with cross-section of the spleno-colic ligament. Then, the gastrosplenic ligament was sectioned and short gastric vessels were closed with clips, Ultracision or LigaSure coagulation. The posterior margin was mobilized until the upper pole by cutting the spleno-renal ligament. Subsequently, the spleno-phrenic ligament was sectioned. After liberation of the organ, the pedicle of the spleen was closed. Vessels were not isolated and ligated individually, but cross-sectioned with either linear stapler or LigaSure placed as close to the hilus as possible. Additionally, a self-strangulating loop was placed on the stump of the pedicle. The spleen, liberated from adhesions and devascularized, was then placed in a plastic bag. When significant splenomegaly was present, the spleno-phrenic ligament was cut at this point. Any additional procedures (cholecystectomy, cholecystotomy, devascularization in oesophageal varices and fundoplication) were performed after changing to the supine position and repositioning of the trocars. The excised spleen was removed via the widened port site above the umbilicus after fingercrashing the spleen inside the bag. No mechanical tools were used for homogenization.

\section{Method of the study}

The study was based on a chart review of patients' documentation. Patients were divided into 3 groups according to surgical technique of ligation of the vessels and applied surgical instruments. Patients were operated with new instruments as soon as they were available; hence the groups were sequential and there were no inclusion or exclusion criteria for any of the groups.

The first group of patients (I) had short gastric vessels clipped with vascular clips and the pedicle of the spleen was sutured with a linear stapler. The second, most numerous group (II) was formed of patients who were operated on with an ultrasonic knife. Again, the pedicle of the spleen was stapled with a linear stapler. The third group (III) consisted of patients operated on after introduction of high-energy coagulation LigaSure, which was used for closure of both short gastric vessels and closure of the pedicle of the spleen. The original bag was used for removal of the spleen from the peritoneal cavity.

To assess surgical technique in each group, duration of the procedure, complications, conversion rate, discharge volume from the peritoneal cavity, duration of analgesia and length of hospital stay were included in the analysis $[2,3,8]$.

\section{Cost analysis}

Economic analysis was based on the costs of procedures at the time of data analysis. Direct cost was summarized, paying special attention to the prices of instruments used and adding them to averaged hospitalization time, according to the specific hospital price list. To compare treatment costs with other data, the dollar exchange rate from 22 February 2009 equal to 3.8 zlotys was taken.

\section{Statistical analysis}

Statistical analysis was performed with ANOVA method of variance analysis to assess distribution of each parameter in different groups of the study. Results are shown as absolute numbers, percentages and means with standard deviation (SD). $P$ value of less than 0.05 was considered significant.

\section{Results}

General data and indications for surgery are shown in Tables I and II. Table III presents additional surgical procedures performed with splenectomy. Mentioned pancreatic tail resection needed splenectomy for infiltration of the tumour on the splenic vessels.

Duration of splenectomy ranged between 30 and $330 \mathrm{~min}$, with mean of $112 \pm 53.11 \mathrm{~min}$. Length of the operation was significantly affected by additional procedures performed (Figure 2). In the first group the procedure lasted 120-300 min, mean 225 $\pm 61.8 \mathrm{~min}$. When patients subjected solely to splenectomy were taken into consideration, the time range did not change yet average time decreased to 201 $\pm 79.08 \mathrm{~min}$. In the second group mean duration of the procedure was $134 \pm 92.8 \mathrm{~min}$ and ranged between 30 and 365 min. Duration of splenectomy when no other surgery was performed was 105 \pm 41.87 min (range: $30-180 \mathrm{~min}$ ). Surgery in the third group took anywhere between 60 and 200 min, with a mean of $100 \pm 36.85 \mathrm{~min}$. When complex procedures were excluded, this time ranged from 60 to $135 \mathrm{~min}$ (mean $90 \pm 24.2 \mathrm{~min}$ ). The difference in duration of surgery in each group was statistically significant ( $p=0.00062$ for all procedures and $p=0.0007$ for procedures limited to splenectomy). 
Table II. Indications for splenectomy in each group

\begin{tabular}{|c|c|c|c|c|}
\hline Indications & I & $\|$ & III & Total \\
\hline Spherocytosis & $10(83.3 \%)$ & $25(48 \%)$ & $5(38.4 \%)$ & $40(51.9 \%)$ \\
\hline $\begin{array}{l}\text { Chronic idiopathic thrombocytopenia resistant } \\
\text { to conservative treatment }\end{array}$ & $1(8.3 \%)$ & $13(25 \%)$ & $7(53.8 \%)$ & $21(27.3 \%)$ \\
\hline Thrombocytopenia resulting from chemotherapy & & $2(3.8 \% \%)$ & & $2(2.6 \%)$ \\
\hline Non-spherocytic haemolytic anaemia & & $2(3.8 \%)$ & $1(7.7 \%)$ & $3(3.9 \%)$ \\
\hline Hodgkin lymphoma & & $1(1.9 \%)$ & & $1(1.3 \%)$ \\
\hline Tumour of the pancreas & & $1(1.9 \%)$ & & $1(1.3 \%)$ \\
\hline Cyst of the spleen & $1(8.3 \%)$ & $2(3.8 \%)$ & & $3(3.9 \%)$ \\
\hline Portal hypertension & & $6(11.5 \%)$ & & $6(7.8 \%)$ \\
\hline Total & $12(100 \%)$ & $52(100 \%)$ & $13(100 \%)$ & $77(100 \%)$ \\
\hline
\end{tabular}

Table III. Procedures accompanying splenectomy

\begin{tabular}{|c|c|c|c|c|}
\hline Type of surgery & I & II & III & Total \\
\hline Cholecystectomy & $2(16.6 \%)$ & $6(11.5 \%)$ & $2(15.4 \%)$ & $10(13 \%)$ \\
\hline Cholecystotomy & $3(25 \%)$ & & $1(7.7 \%)$ & $4(5.2 \%)$ \\
\hline Devascularization of the oesophagus and fundoplication & & $6(11.5 \%)$ & & $6(7.8 \%)$ \\
\hline Resection of the tail of the pancreas & & $1(1.9 \%)$ & & $1(1.3 \%)$ \\
\hline Total & $5(41.6 \%)$ & $13(25 \%)$ & $3(23 \%)$ & $21(27.3 \%)$ \\
\hline
\end{tabular}

Mean hospitalization time was $4.07 \pm 1.95$ days and ranged from 2 to 18 days. Hospital care longer than 4 days was forced by complications which had occurred during surgery or in the postoperative period. Patients from the first group were hospitalized for a mean of $3.75 \pm 1.48$ days, from the second group for $4.23 \pm 2.24$ days, and from the third group for 3.76 \pm 0.59 days. Differences between the groups were insignificant $(p=0.61)$.

Opioid painkillers were administered in 3-4 doses a day given intravenously, subcutaneously or intramuscularly. These drugs were given for 1-4 days after surgery (mean $2.05 \pm 0.75$ days). No significant difference was found between the groups. Oral feeding was started on the second postoperative day. Delay in oral nutrition occurred in two patients only and was due to complications of surgery.

Drainage of the surgical site was not used routinely - the decision was left to the surgeon. Finally, drainage was used in 57 patients, with volume range of $0-270 \mathrm{ml}$ (mean $51.6 \mathrm{ml}$ ). As the study was performed in paediatric patients, we have corrected the draining volume for body weight. Average for the whole population was $1.7 \pm 6.7 \mathrm{ml} / \mathrm{kg}$. In the first group it was $1.08 \pm 1.5 \mathrm{ml} / \mathrm{kg}$, in the second $2.03 \pm 8.1$ $\mathrm{ml} / \mathrm{kg}$, and in the third $0.97 \pm 1.3 \mathrm{ml} / \mathrm{kg}$. Hence, proportional discharge volumes for an adult of $70 \mathrm{~kg}$ would be, respectively: 75.6, 142.1 and $67.9 \mathrm{ml}$ in the first, second and third group. This result is also statistically not significant $(p=0.82)$.

Adverse events occurred in 10 patients (12.98\%) included in the study. Distribution of adverse events in each group is shown in Table IV.

Fixed costs of the laparoscopic splenectomy including disposable materials and equipment and calculated amortization of preparation tools and laparoscope were 433.17 zlotys. The laparoscopic bag for spleen removal was 250 zlotys. A clip applicator 
costs 467 zlotys a charge and 10 zlotys for tool amortization. The stapler price was 2208 zlotys. Ultrasonic knife amortization for each procedure was calculated at 134.45 zlotys. Application of the LigaSure vessel closure system was calculated at 1980 zlotys. Mean cost of hospitalization was 2253.96 zlotys. Total cost was, respectively 5622.10 zlotys when bipolar coagulation, clip applier and vascular stapler were used, 5279.58 when Ultracision was applied, and 4917.13 zlotys when the LigaSure system was used. Costs are presented in Figure 3.

\section{Discussion}

In the presented study the surgical procedure and post-operative course were analyzed in 77 children operated on between 1996 and 2007. All procedures were performed with the laparoscopic method. Haematological diseases prevailed $(n=66)$, as they are the leading indication for elective splenectomy in the literature [4-6, 9-21]. Patients with hypersplenism accompanying portal hypertension formed another group [6, 11, 22-24], who had devascularization of the oesophagus and gastric fundus with splenectomy as an alternative to other procedures in recurrent bleeding from oesophageal varices after primary therapy with endoscopic sclerotherapy [6, 23].

The technique of laparoscopic splenectomy in our experience is similar to that presented in the majori-

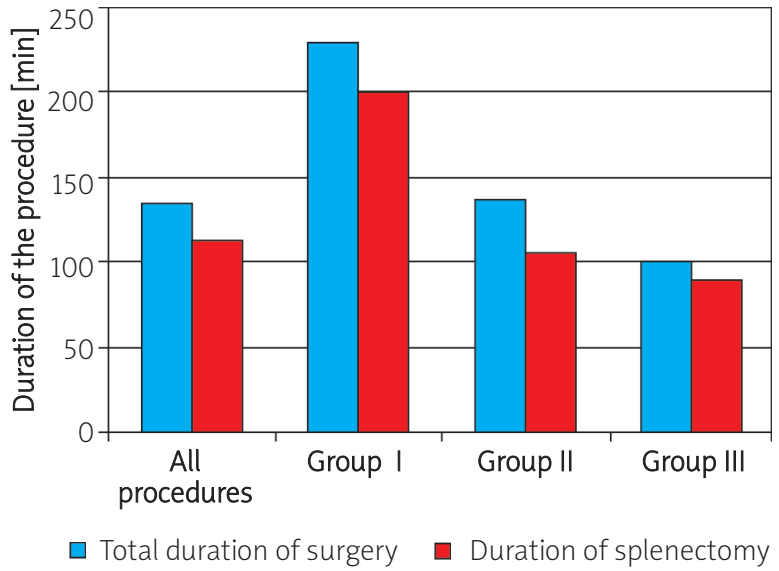

Figure 2. Mean duration of splenectomy with and without additional procedures

ty of international publications. Position on the right side at 45 or $90^{\circ}$ and support of the lumbar region is preferred [12, 16, 20, 25, 26]. Most authors, like ourselves, have chosen this position after trying the classic supine position first $[17,18,21,27,28]$. According to Rescorla and Szold, mobilization of the whole spleen ('suspended pedicle') allows for safe placement of the stapler on the vessels of the pedicle by lifting it on the lower jaw of the instrument. An undivided spleno-phrenic ligament can obscure the view of the tool tip, creating the risk of incomplete closure

Table IV. Side effects in each group

\begin{tabular}{|c|c|c|c|c|c|c|}
\hline Type of complication & $\begin{array}{l}\text { Operative technique } \\
\text { dependent }\end{array}$ & 1 & II & III & Total & $\begin{array}{l}\text { Statistical } \\
\text { significance }\end{array}$ \\
\hline $\begin{array}{l}\text { Bleeding to the peritoneal cavity } \\
\text { requiring re-laparoscopy }\end{array}$ & Yes & & $2(3.84 \%)$ & & $2(2.59 \%)$ & \\
\hline Subphrenic abscess & Yes & & $1(1.92 \%)$ & & $1(1.29 \%)$ & \\
\hline Subcutaneous emphysema & No & & $1(1.92 \%)$ & & $1(1.29 \%)$ & \\
\hline $\begin{array}{l}\text { Need for mechanical ventilation } \\
\text { after surgery }\end{array}$ & No & & $1(1.92 \%)$ & & $1(1.29 \%)$ & \\
\hline Vomiting & No & & $1(1.92 \%)$ & & $1(1.29 \%)$ & \\
\hline $\begin{array}{l}\text { Superficial vein thrombosis } \\
\text { of the upper limb }\end{array}$ & No & & & $1(7.69 \%)$ & $1(1.29 \%)$ & \\
\hline Infection of upper airways & No & & $1(1.92 \%)$ & & $1(1.29 \%)$ & \\
\hline Conversion & Yes & & $2(3.84 \%)$ & & $2(2.59 \%)$ & \\
\hline Total & & 0 & $9(17.3 \%)$ & $1(7.69 \%)$ & $10(12.98 \%)$ & $p=0.10$ \\
\hline
\end{tabular}




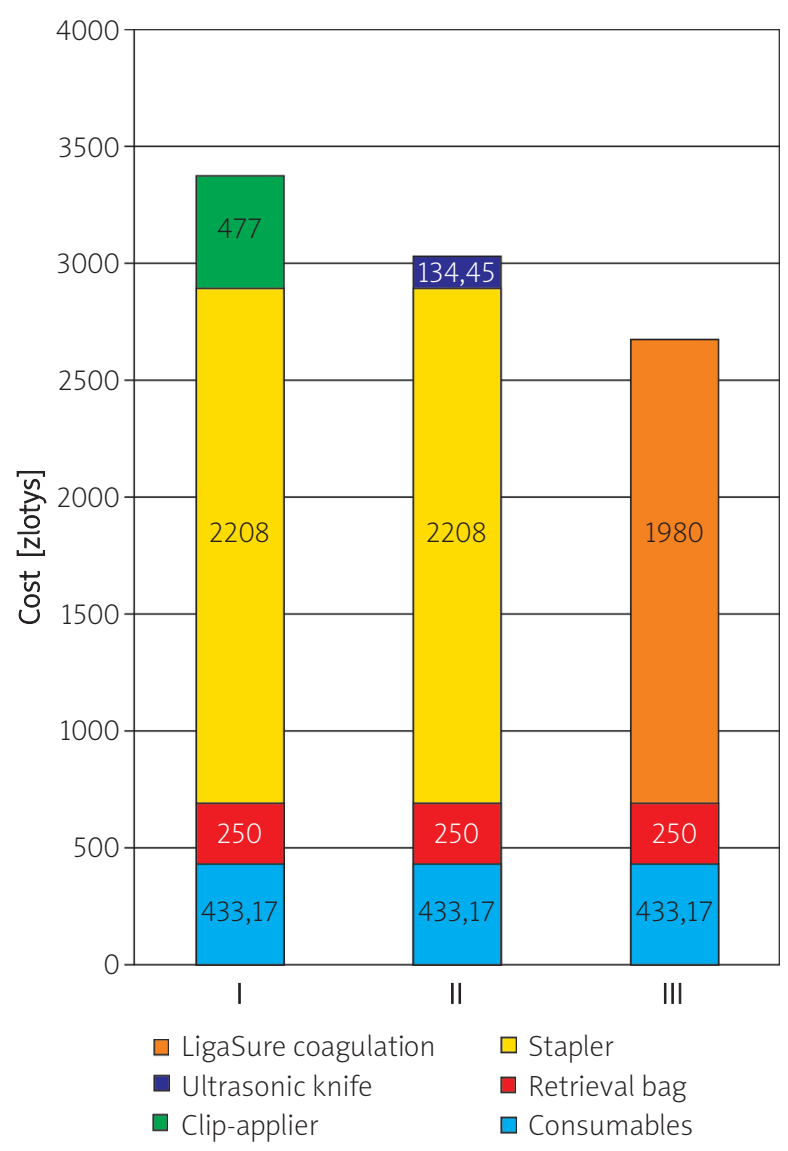

Figure 3. The cost of laparoscopic splenectomy

of the pedicle with mechanical suture [12] or damage to the vessels [25]. Neither of these authors, however, had observed such a complication in his material, and nor did we. Klingler suggests that both modifications are equally safe and appropriate, and the choice is only up to the surgeon [29]. We left the splenophrenic ligament untouched until the pedicle was sectioned only when significant splenomegaly was present to facilitate manoeuvring of the organ on placement within an endobag. We have not adopted the 'vessels first' technique with ligation of the splenic artery and vein, as preparation of the pedicle in an omental bursa with immobilized spleen is difficult and time-consuming and increases the risk of injury to the tail of the pancreas. On the other hand, an effect of autotransfusion is hypothetical and cannot be confirmed during the surgery. Our experience and literature data both discourage this modification [25]. Stapler placement on the whole pedicle without division of the vein and artery is considered the safest means of ligation. It minimized the risk of vascular damage on dissection and shortened operation time $[25,29]$.

In the presented study, mean surgery duration was 135 and 112 min when patients with complex surgery were excluded. Systematic shortening of the time needed to complete the procedure was noted: from 201 min needed for splenectomy in group I to 90 min in group III. The meta-analysis performed by Winslow et al. including 2940 patients from 51 publications has shown that mean duration of laparoscopic splenectomy $(180 \mathrm{~min}$ ) exceeded that of classical splenectomy (114 $\mathrm{min}$ ) [30]. This is considered one of the major disadvantages of laparoscopic splenectomy. We were able to reduce operation time significantly. Our experienced team, equipped with modern instruments (group III), was able to accomplish laparoscopic surgery in a shorter time than that of classical splenectomy given by Winslow [30].

We did not observe any difference in hospital stay during the study period; the mean was 4.07 days. When hospitalization lasted longer than 4 days, it resulted from intra- or post-operative complications, which are described below. The most important factor allowing for assessment of the adopted surgical technique is the rate of peri-operative complications and conversion rate in laparoscopic procedures [3136]. We have studied the number of adverse events. An adverse event was any deviation from ideal postoperative course $[3,8]$, hence their high rate $(12.98 \%)$. However, only 3 events in this group were related to surgical technique $(3.89 \%$ of the study population). The most common complication was bleeding into the peritoneal cavity, which occurred twice $(2.59 \%)$. Both cases were treated with relaparoscopy. Blood was present in the post-splenectomy site and in a Douglas recess. No source of active bleeding was found. Blood was washed out and drainage was placed. In Winslow's meta-analysis haemorrhage was described in $4.8 \%$ of patients, including the need for conversion for intraoperative bleeding and $1.6 \%$ if conversions were excluded [30]. Other authors mentioned above report a hemorrhagic complication rate of 0 to $5.5 \%[8,12,16,17,22,29$, $33,34]$. In our group two patients $(2.59 \%)$ needed conversion to open procedure. One of these cases was a combined procedure of splenectomy, devascularization of oesophagus, and gastric fundoplication. Conversion was performed after successful splenectomy due to difficulties in devascularization of the 
cardia region and distal oesophagus. The second case decision to convert was made due to extreme size of the spleen, as the organ, $28 \times 16 \mathrm{~cm}$ in size, ran down as low as the umbilicus. Laparotomy was performed after the organ was cut off, as it was impossible to remove it from the abdomen and the length of incision was only $8 \mathrm{~cm}$. Conversion to open procedure is a controversial issue. Such a decision is usually made due to intraoperative complications (bleeding) or due to the size of the spleen exceeding the technical possibility of excision. Such a change of technique must always be acceptable. Literature data are contradictory and many do not consider abdominal incision a conversion whenever oncological guidelines require removal of the spleen in one piece $[14,17,36]$. Patel considered the procedure minimally invasive when the skin incision did not exceed $5 \mathrm{~cm}$ [34]. The authors agree that the number of conversions decreases with experience of the surgeon, and together with duration of surgery is a criterion of learning curve assessment [17, 34, 33]. In our material, conversions were not related to the technique of spleen preparation or possible complications.

Total cost of the procedure differs between centres and countries. In the publication of Misiak et al. from 2004 the total cost of treatment was calculated as 7024 zlotys [37]. The cost of splenectomy in the US is 7584 dollars (28 819 zlotys) according to Corder et al. [38]. Turkish data give an amount of 2064 dollars (7843 zlotys) [16]. In China the cost of splenectomy was calculated as a mean of 871 dollars (3309 zlotys) [24]. In our material, the biggest part of the total cost of laparoscopic splenectomy depends on the price of the consumable tools, which in Poland is significantly higher (in comparison to other costs of treatment) than in western countries. At the same time, the average cost of a day of hospitalization in a surgical unit with labour costs is incomparably lower and is given as an averaged cost, without precise calculation of time in the operative room or inclusion of perioperative procedures cost. Hence, an increase of the cost with laparoscopic method (mostly driven by the cost of the tools) is proportionally much more significant than the obvious and proven benefit of laparoscopy with shortened hospitalization time [37]. Cost analysis should be followed by an idea to decrease them. Turkish authors working in economic conditions and instruments/hospitalization cost ratios similar to the Polish conditions put forth such a proposition [16, 39]. As the increased cost of laparo- scopic splenectomy is mostly driven by the price of tools, especially disposable ones, they suggest reusing them. Yünney and Hamamci confirm in practice, with results of bacteriological studies, that preparation tools, trocars and the LigaSure device can be successfully re-sterilized and re-used [16, 39]. The cost of a single application of LigaSure coagulation is 1980 zlotys. Considering 4 or 5-time usage of LigaSure coagulation, according to Yüney's publication, the cost for a single procedure would be 396 zlotys [39]. Unfortunately, according to American and EU standards such a solution cannot be applied. Multiple-use LigaSure device could be such a solution.

The presented data show that the laparoscopic procedure brings little risk to a patient, independently of the applied technique. Improvements in disposable equipment, especially the possibility to re-use LigaSure coagulation, significantly reduce the duration of surgery and decrease its cost.

\section{Conclusions}

1. Application of different surgical techniques does not influence the complication rate when surgery is performed by the same, experienced team.

2. Introduction of sterilizable instruments, especially LigaSure coagulation, significantly reduces cost of the procedure.

\section{References}

1. Tulman S, Holcomb GW, Karamanoukian HL, et al. Laparoscopic splenectomy. J Pediatr Surg 1993; 28: 689-92.

2. Rescorla FJ, Engum SA, West KW, et al. Laparoscopic splenectomy has become the gold standard in children. Am Surg 2002; 68: 297-301.

3. Franciosi C, Caprotti R, Romano F, et al. Laparoscopic versus open splenectomy: a comparative study. Surg Laparosc Endosc Percutan Tech 2000; 10: 291-5.

4. Treliński J. Współczesne metody leczenia immunotrombocytopenii samoistnej. Acta Haematol Pol 2006; 37 supl. 4: 93-101.

5. Adamowicz-Salach A, Matysiak M, Albrecht-Stanisławska K. Niedokrwistości hemolityczne związane z wrodzonym niedoborem białek błony komórkowej krwinek czerwonych - diagnostyka i leczenie. Klin Pediatr 2005; 13: 327-32.

6. Pawlak J, Małkowski P, Michałowicz B. Krwotok z żylaków przełyku - standardy diagnostyczne i lecznicze. Stand Med Lek Rodz 2002; 3: 352-74.

7. Jackowska T. Zapobieganie zakażeniom bakteryjnym u dzieci z brakiem lub dysfunkcją śledziony. Essent Med 2006; 4: 66-68, 70, 72.

8. Targarona EM, Espert JJ, Bombuy E, et al. Complications of laparoscopic splenectomy. Arch Surg 2000; 135: 1137-40. 
9. Matzdorff A, Arnold G. Treatment of chronic immune thrombocytopenic purpura: the patients' perspective. Eur J Haematol 2007; 78: 381-8.

10. Al-Salem AH. Indications and complications of splenectomy for children with sickle cell disease. J Pediatr Surg 2006; 41: 1909-15.

11. Teisseyre M, Oralewska B, Kaliciński P, et al. Metody leczenia nadciśnienia wrotnego u dzieci z mukowiscydozą. Pediatr Pol 2002; 77: 19-25.

12. Rescorla F, West K, Engum S, Grosfeld J. Laparoscopic splenic procedures in children. Experience in 231 children. Ann Surg 2007; 246: 683-8.

13. Khoursheed M, Al-Sayegh F, Al-Bader I, et al. Laparoscopic splenectomy for hematological disorders. Med Princ Pract 2004; 13: $122-5$.

14. Rhodes M, Rudd M, O’Rourke N, et al. Laparoscopic splenectomy and lymph node biopsy for hematologic disorders. Ann Surg 1995; 222: 43-6.

15. Caprotti R, Franciosi C, Romano F, et al. Combined laparoscopic splenectomy and cholecystectomy for the treatment of hereditary spherocytosis: is it safe and effective? Surg Laparosc Endosc Percutan Tech 1999; 9: 203-6.

16. Hamamci EO, Besim H, Bostanoglu S, et al. Use of laparoscopic splenectomy in developing countries: analysis of cost and strategies for reducing cost. J Laparoendosc Adv Surg Tech A 2002; 12: 253-8.

17. Patkowski D, Chrzan R, Wróbel G, et al. Laparoscopic splenectomy in children: experience in a single institution. J Laparoendosc Adv Surg Tech A 2007; 17: 230-4.

18. Silecchia G, Boru CE, Fantini A, et al. Laparoscopic splenectomy in the management of benign and malignant hematologic diseases. JSLS 2006; 10: 199-205.

19. Zitsman JL. Current concepts in minimal access surgery for children. Pediatrics 2003; 111: 1239-52.

20. Sandoval C, Stringel G, Ozkaynak MF, et al. Laparoscopic splenectomy in pediatric patients with hematologic diseases. JSLS 2000; 4: 117-20.

21. Liu DC, Meyers MO, Hill CB, Loe WA Jr. Laparoscopic splenectomy in children with hematological disorders: preliminary experience at the Children's Hospital of New Orleans. Am Surg 2000; 66: 1168-70.

22. Park A, Marcaccio M, Sternbach M, et al. Laparoscopic vs open splenectomy. Arch Surg 1999; 134: 1263-9.

23. Hashizume M, Tanoue K, Morita M, et al. Laparoscopic gastric devascularization and splenectomy for sclerotherapy-resistant esophagogastric varices with hypersplenism. J Am Coll Surg 1998; 187: 263-70.

24. Chen B, Hu S, Wang L, et al. Economical strategies of laparoscopic splenectomy: a Chinese single-center experience. Chir Gastroenterol 2007; 23: 387-91.

25. Szold A, Sagi B, Merhav H, Klausner JM. Optimizing laparoscopic splenectomy. Technical details and experience in 59 patients. Surg Endosc 1998; 12: 1078-81.

26. Danielson PD, Shaul DB, Phillips JD, et al. Technical advances in pediatric laparoscopy have had a beneficial impact on splenectomy. J Pediatr Surg 2000; 35: 1578-81.

27. Schaarschmidt K, Kolberg-Schwerdt A, Lempe M, Saxena A Ultrasonic shear coagulation of main hilar vessels: a 4-year experience of 23 pediatric laparoscopic splenectomies without staples. J Pediatr Surg 2002; 37: 614-6.

28. Rescorla FJ, Breitfeld PP, West KW, et al. A case controlled comparison of open and laparoscopic splenectomy in children. Surgery $1998 ; 124$ : 670-5.

29. Klingler PJ, Tsiotos GG, Glaser KS, Hinder RA. Laparoscopic splenectomy: evolution and current status. Surg Laparosc Endosc 1999; 9: 1-8.

30. Winslow ER, Brunt LM. Perioperative outcomes of laparoscopic versus open splenectomy: a meta-analysis with an emphasis on complications. Surgery 2003; 134: 647-55.

31. Patel AG, Parker JE, Wallwork B, et al. Massive splenomegaly is associated with significant morbidity after laparoscopic splenectomy. Ann Surg 2003; 238: 235-40.

32. Cusick RA, Waldhausen JH. The learning curve associated with pediatric laparoscopic splenectomy. Am J Surg 2001; 181: 393-7.

33. Casaccia M, Torelli P, Squarcia S, et al. Laparoscopic splenectomy for hematologic diseases: a preliminary analysis performed on the Italian Registry of Laparoscopic Surgery of the Spleen (IRLSS). Surg Endosc 2006; 20: 1214-20.

34. Patel AG, Parker JE, Wallwork B, et al. Massive splenomegaly is associated with significant morbidity after laparoscopic splenectomy. Ann Surg 2003; 238: 235-40.

35. Chen MK, Schropp KP, Lobe TE. Complications of minimalaccess surgery in children. J Pediatr Surg 1996; 31: 1161-5.

36. Budzyński A, Rembiasz K, Biesiada Z, et al. Laparoskopowe operacje narządów miąższowych. Pol Przegl Chir 2006; 78: 257-70.

37. Misiak A. Szczepanik AB, Huszcza SR, et al. Splenektomia laparoskopowa a splenektomia klasyczna w małopłytkowości samoistnej - porównanie kosztów i ocena wczesnych wyników. J Pol Przegl Chir 2004; 76: 607-17.

38. Cordera F, Long KH, Nagorney DM, et al. Open versus laparoscopic splenectomy for idiopathic thrombocytopenic purpura: clinical and economic analysis. Surgery 2003; 134: 45-52.

39. Yüney E, Höbek A, Keskin M, et al. Laparoscopic splenectomy and LigaSure. Surg Laparosc Endosc Percutan Tech 2005; 15 : 212-5. 